\title{
Johan Derksen als sleutelfiguur
}

\author{
Citation for published version (APA):
}

Stokkom, B., \& Janssen, J. H. L. J. (2020). Johan Derksen als sleutelfiguur. Tijdschrift over Cultuur \& Criminaliteit, 2020(2), 98-99. https://www.bjutijdschriften.nl/tijdschrift/tcc/2020/2/TCC_2211-

9507_2020_010_002_007

Document status and date:

Published: 01/01/2020

Document Version:

Publisher's PDF, also known as Version of record

\section{Document license:}

\section{Taverne}

Please check the document version of this publication:

- A submitted manuscript is the version of the article upon submission and before peer-review. There can be important differences between the submitted version and the official published version of record. People interested in the research are advised to contact the author for the final version of the publication, or visit the DOI to the publisher's website.

- The final author version and the galley proof are versions of the publication after peer review.

- The final published version features the final layout of the paper including the volume, issue and page numbers.

Link to publication

\section{General rights}

Copyright and moral rights for the publications made accessible in the public portal are retained by the authors and/or other copyright owners and it is a condition of accessing publications that users recognise and abide by the legal requirements associated with these rights.

- Users may download and print one copy of any publication from the public portal for the purpose of private study or research.

- You may not further distribute the material or use it for any profit-making activity or commercial gain

- You may freely distribute the URL identifying the publication in the public portal.

If the publication is distributed under the terms of Article 25fa of the Dutch Copyright Act, indicated by the "Taverne" license above, please follow below link for the End User Agreement:

https://www.ou.nl/taverne-agreement

Take down policy

If you believe that this document breaches copyright please contact us at:

pure-support@ou.nl

providing details and we will investigate your claim.

Downloaded from https://research.ou.nl/ on date: 26 Apr. 2023 


\title{
DISCUSSIE
}

\section{Johan Derksen als sleutelfiguur}

\author{
Bas van Stokkom \& Janine Janssen
}

Tijdens een redactievergadering over dit themanummer in het najaar van 2019 werd het idee geopperd om de wederwaardigheden van een populaire tussenpersoon in de sportwereld op luchtige wijze te belichten. De keuze viel meteen op Johan Derksen. Hij is geen voetbalmakelaar of zaakwaarnemer die in het schemergoed aan transfersommen verdient, maar geldt als verbindingsman die in de volle openbaarheid het voetbalminnende publiek van amusement voorziet. Besloten werd een voorstander en tegenstander van deze mediaheld aan het woord te laten, te weten Janine Janssen en Bas van Stokkom. Eerstgenoemde redacteur is gefascineerd door Johan en kijkt regelmatig naar het theater dat de heren van Veronica Inside voorschotelen, de ander vindt Derksens carrière prototypisch voor tribunen die binnen commerciële branches van volksvermaak furore maken, ook al is dat soms tegen wil en dank.

De twee stukken die de lezer op de volgende pagina's aantreft, zijn geschreven voordat het coronavirus de samenleving min of meer platlegde. Tijdens die crisis implodeerde de voetbalbranche. 'Wat is nu nog je identiteit als voetballer?' kopte Trouw op 28 april van dit jaar. Een wereldwijde enquête liet zien dat een kwart van de voetballers met depressieve gedachten en angstgevoelens kampte. Veel contracten werden opgezegd, de sterrenstatus brokkelde af en de veelverdieners stonden anoniem aan de zijlijn geparkeerd. KNVB-directeur Eric Gudde zei in dat verband dat de pandemie aanleiding geeft tot een 'natuurlijke zelfreiniging van de industrie'. We moeten 'realistischer worden over de geldstromen en beseffen dat de tijd van grote transferbedragen wel voorbij is' (Trouw, 20 mei). Zal de discussie over sanering en regulering van de branche nu echt van de grond komen? Voor het Mediapark is dat waarschijnlijk bijzaak. Zodra de bal weer rolt, kan het publiek weer voorzien worden van roddel, kift, provocatie, hete emoties en idolatrie.

In juni 2020 is Veronica Inside, het podium waarop Derksen wekelijks acte de présence geeft, zwaar onder vuur komen te liggen. Aanleiding was een grap van Derksen over de rapper Akwasi. Een foto van een antiracismedemonstrant verkleed als Zwarte Piet ontlokte bij hem de uitspraak: 'Weten we zeker dat dat niet Akwasi is?' De grap mondde uit in een heuse rel. Sommige adverteerders van het programma haakten af en spelers van het Nederlands elftal lieten weten zich niet meer te laten interviewen door Veronica Inside. De ophef kan geplaatst worden tegen de achtergrond van het hardnekkige racismeprobleem in de voetballerij en de wereldwijde felle antiracismedemonstraties na de gewelddadige dood van George Floyd door buitensporig politieoptreden in Minneapolis. 
Na alle commotie wilde Johan Derksen stoppen met het programma. Presentator Wilfred Genee zou het programma hebben 'opgeblazen' met de bewuste uitzending. Doorgaan met het programma zou volgens Derksen zinloos zijn: 'Als we daar nu gaan zitten, zijn we ongeloofwaardig, karakterloos en gaan we er ordinair voor de poen zitten.' ${ }^{1}$ Mediatycoon en Talpa-baas John de Mol greep vervolgens eigenhandig in en wees de ruziemakers op hun contractverplichtingen. Derksen zegde vervolgens gedwee toe na de zomerstop verder te gaan met Veronica Inside en beloofde - om niet over te komen als een zakkenvuller - de helft van zijn salaris aan goede doelen te schenken. 